\title{
The Formation of Sino-Burmese Cultural Frontier and Its Governance
}

\author{
Yan Xiong \\ Yunnan University of Finance and Economics \\ Kunming Yunnan, 650221
}

\author{
Xia Han \\ Yunnan University of Finance and Economics \\ Kunming Yunnan, 650221
}

\begin{abstract}
Under the tide of globalization, how to maintain the national cultural frontier security has become an important subject to build a harmonious and stable frontier. This paper defines Sino-Burmese frontier from cultural perspective, analyzes the importance of the frontier national culture towards national cultural security and its practical influence. It explores the governance path of Sino-Burmese cultural frontier from the perspective of cultural security on aspects such as giving full play to the role of civil organization, improving the religious governance mechanism, promoting the development of national cultural industry and improving the public culture service system, so as to promote the in-depth implementation of "One Belt And One Road" strategy and the friendly development of ChinaBurma relationship.
\end{abstract}

Keywords-Sino-Burmese cultural frontier; formation; governance

\section{INTRODUCTION}

China is closely connected with Burma. The adjacent geographical environment, cross-nation cultural exchanges and trades have formed a cultural frontier, which goes beyond the traditional geographical border concept. National culture is the cultural and historical accumulation of a country and nation. In the context of globalization, the cultural integration is affecting the trend of national culture of different countries in the world. The interaction between different cultures makes cultural diversity exist in border areas for a long time. While making the frontier culture more prosperous, it also brings challenges to national cultural security. National ideological security is essential to the country and nation. It is directly related to national security and social stability. Therefore, maintaining the national frontier ideological security has become the top priority in protecting national security. SinoBurmese cross-border areas are mostly in Yunnan area. Yunnan is positioned as "the radial center facing South Asia and Southeast Asia" in the "One Belt And One Road" strategy. Therefore, Sino-Burmese cultural frontier governance is of great importance for the implementation of China's "One Belt And One Road" strategy and the security of its southwest border areas

\section{THE CONNOTATION AND CHARACTERISTICS OF CULTURAL FRONTIER}

\section{A. The Concept of Cultural Frontier}

Academic circles don't have much research about the concept of cultural frontier. Scholar Eva Hung argues that cultural frontier refers to communities at the national borders that are influenced by binary or diverse culture. [1]Scholar Yang Cheng believes that the cultural frontier refers to the objective existence of a country's culture, ideas, and beliefs within and outside the national boundaries. [2]Scholar Xu Lili believes that cultural boundaries may be greater or less than the national boundaries. [3]Thus, the cultural frontier is the embodiment of nation-culture relationship in the border areas, and is the inviolable defense boundary of the culture of a sovereign nation.

\section{B. The Characteristics of Cultural Frontier}

As a frontier extension of the geopolitics, cultural frontier has many characteristics.

1) Cultural frontier is merging. The ethnic groups in the multi-ethnic countries have their own cultural identity, but the cultures of the various ethnic groups are merging and gradually form some common cultural characteristics, so that all ethnic groups have a common cultural psychology and form a national cultural security barrier.

2) Cultural frontier is susceptible. There are some differences between the mainstream ideologies, cultural characteristics and religious beliefs of different countries. The border areas are more susceptible to the cultural influence of neighboring countries and other ethnic groups because of their special geographical location, thus forming complicated frontier culture. [4]

3) The objective existence of cultural frontier. Cultural frontier is of objectivity, applicable to all countries with normal external exchange. Each country, regardless of its size or strength, all have cultural frontier issues. 


\section{The Formation OF SinO-Burmese CulturaL FRONTIER}

The total length of Sino-Burmese border line is 2185 kilometers, of which Yunnan section is 1997 kilometers, and multiple ethnic groups live across the border. [5]Cross-border ethnic group refers to ethnic groups separated in two or several countries by national boundaries. Although they belong to different countries, they have the same living habits, language, and religious beliefs. Of the 25 ethnic minorities in Yunnan, 15 ethnic groups are located in the Sino-Burmese border areas. These cross-border ethnic groups believe in the same religion, and maintain close contact based on ethnicity and kinship ties in the same ethnic group. They have mutual influence and penetrations on culture, thought, life and customs, and have many cross-border cultural interactions and frequent exchanges, providing necessary conditions and important basis for the formation of Sino-Burmese cultural frontier.

Common religions, customs and language also provide a broader interactive space for the ethnic minorities at the SinoBurmese border and neighboring countries. They interact and learn from each other in the long-term history, spread their religious culture and values, so that the border areas not only have distinctive national characteristics, but also form a crossborder culture and exotic charm because of the influence of neighboring culture. It promotes the prosperity of the frontier national culture and forms unique cultural frontier.

\section{AN ANALYSis OF THE UNSTABle FACTORS AFFECTING THE SECURITY OF SinO-BURMESE FrONTIER CULTURE}

In the context of globalization, cross-border cultural exchanges are deepening, culture plays an important role in the field of ideology, and cultural security becomes an increasingly prominent problem in the world.

\section{A. The Impact of Ideological Field}

In recent years, based on the special situation of multiethnic habitation and economic backwardness in the SinoBurmese border areas, foreign forces often use the same ethnicity and religious belief to carry out multi-angle and allround penetration and malicious attacks to our country, and use various means to create conflicts. [6]It has become an important issue to resist cultural infiltration, and maintain national political peace and cultural security. With the expansion of the opening to the outside world and the popularity of network information, the ideological security situations in border areas also become more and more serious.

\section{B. Insufficient Supply of Cultural Products}

The economic development of frontier national areas is lagging behind. It lacks of cultural products, and can not meet people's needs on cultural life, leading to the prominent phenomenon of foreign cultural products being introduced into China. In recent years, foreign forces infiltrate China's border areas through leaflets, brochures, and books, conduct missionary infiltration towards religious people, which has seriously affected the normal production and living order of the people at border areas, and the harmony and stability of border areas, and brought challenges to the cultural security in Sino-Burmese border areas.

\section{Complex Religious Beliefs}

Located in the Sino-Burmese border area, Mangshi town in Dehong prefecture is a county with multi-ethnic and multireligious denominations. There are many religious people, mainly distributed in villages along the border line, such as Mangshi town, Fengping town and Zhongshan village. The situation is very complex. Foreign religious forces often use the missionary work to interfere with local unity and stability.[7]

\section{Thoughts on Perfecting the Strategies of CULTURAL FrontiER REGULATION}

\section{A. Perfect Religion Governance Mechanism and Resisting the Religious Infiltration}

1) Earnestly Implement the Policies and Guidelines Carried out by the Party and the Government

The policies and guidelines carried out by our country should be implemented. Publicity and education should be strengthened. Therefore, the religious policy knowledge level of the religious people will be enhanced. Cadres at different levels attach importance to religious work, and the party's religious policy and guiding thought are reflected in the grassroots work. They have fully played the role of all kinds of media and guaranteed the freedom of religion. At the meanwhile, they have guided the mass identify the illegal religion and resist the illegal religious activities.

\section{2) Fully Respect the Masses' Religion Choices}

Communications and notifications of various religious organizations should be strengthened, especially in Buddhism. The conflicts between the religious people who have converted to Buddhism and the original Buddhist should be promptly known and solved through communication, which can promote the understanding. Doing a stable work for religious people will provide better services for socialism new countryside construction and promoting cultural and ideological progress.

3) Strengthen the Personnel Training in Religious People and Clerical Personnel, and Rely on Them to Administer the Vast Religious Believer

Elite and powerful religious workers should be assigned. The religious knowledge training of village cadres and group cadres should be strengthened. It is of great importance to conduct education on religious employees and strengthen the religious people's awareness of legal compliance. Harmonious society and ethnic unity should be taken as the main body and the venues for religious activities and activities should be regulated. Besides, religious believers should be guided to implement the active and healthy activities.

4) All Departments Should Cooperate and Link to Crack Down on Illegal Religious Activities

Every functional department should control and administrate cooperatively and coordinate with each other to deal with the reinforced, guide and management work in 
religion. Under the unified leadership of Party committees and governments at all levels, cooperated with community-level party and government organizations, we should mobilize the forces of the whole society and adopt various methods to fully strengthen social management, through which the various illegal activities can be stopped and the ideological education can be strengthened. We should try to win vast religious people and reduce and eliminate the unstable factors brought by illegal religious culture.

\section{B. Perfect the Public Cultural Service System}

The perfection of Public Cultural Service System needs the corporate safeguard of cultural "software" and "hardware". Cultural service infrastructure is the necessary hardware base, and also the necessary condition for implementing the public cultural activities. Border areas should build grass-roots public cultural facilities, such as cultural centers, libraries, community centers, cultural relic administrations. To ensure that the full coverage should be achieved by all cities, county and township. At the meanwhile, the methods, carrier and platform of promoting the ideology and culture should be innovated actively by the grass-roots unit. They should adopt the beloved and easily understood methods to spread through the platforms of media, television and newspaper, such as scheduling the allegro or sketch which are propagating the party's policy, broadcasting the news, the policy of benefiting people and folk music in local minority languages. They should use healthy and upward culture and thought to take over the rural areas, which not only enrich the lives of the border people, but also effectively spread culture. People's eyesight has been broadened and their thoughts have been updated. Besides, their mental state and live status have been improved imperceptibly.

In the Jiegao Abroad, the cutting-edge of the frontier of China and Burma, located in Ruili, Dehong, Yunnan Province, set up an "Abroad Book Center", which publish Dehong books, newspapers, periodicals and magazines in minority languages. An irreplaceable role has been played in technological progress, anti-drug and Aids prevention and guarding the frontier. And since all the ethnic minorities in the frontier of China and Burma have the same clan and origin, they are keen on buying and reading the various books, newspapers, periodicals and magazines published by Dehong. With the speeding up of the process of globalization, the publishing of Dehong books, newspapers, periodicals and magazines have made new progress in new historical conditions. Dehong "Abroad Book Center" project has become an important platform for culture foreign publicity.

\section{Give Full Play to the Functions of Civil Organizations}

The cultural exchange of civil-organizations does not only enrich people's spiritual life, but also has significant meaning in promoting the harmony of ethnic relations and international relations as an implicit power. In the year of 2013, Ruili has established the Sino-Burmese Border Cultural Exchange Association, which has held the Sino-Burmese Women's New Year Celebration, Sino-Burmese Youth Party, 2014 Overseas Chinese Symposium, 2015 Overseas Chinese Symposium and Sino-Burmese Border Buddhist Culture Exchange Conference.
In the meanwhile, Ruili and Muse City have conducted all kinds of exchange activities actively and achieved favorable social benefit. It has great impact on Sino-Burmese friendly association and promotes harmonious and stability for SinoBurmese Borders.

\section{Promote the Development of Ethnic Culture Industry and Raising the Ethnic Cultural competence}

Sino-Burmese border areas own rich cultural resources and advantaged development superiority. Therefore, according to the special cultural products development thinking of "Gold, Wood, Earth, Stone and Cloth" advocated by Yunnan Province, they should explore to spread and protect the national and folk traditional culture and incorporate its cultural characteristics into cultural products, as well as enhance the influence and seepage force of national culture and strengthen the cultural centripetal force of the frontier nationalities. The construction of characteristic cultural industry village (town) should be continued. The encouragement, guidance and support of rural performance, characteristic dining culture, and traditional cultural craft industry should be emphasized. We should firmly push forward the construction of cultural industry creative industry center, characteristic cultural industry demonstration village and characteristic tourist town. We should promote the development of ethnic culture industry and gradually establish a corresponding cultural system fits China's opening up towards southwest. Ethnic cultural competence will be enhanced. Through the ways of thriving the frontier culture, broadening cultural exchange channels and strengthening the frontier cultural soft power, we will promote the people's livelihood in border areas and maintain the harmony and stability of the border areas.

\section{CONCLUSION}

Based on the special geographic location and national cultural characteristics of Sino-Burmese border areas and in the trend of globalization, cultural frontier has become increasingly prominent. In order to maintain the cultural security in Sino-Burmese border areas and display the positive strength of the cultural frontier, as well as maintain the national security, the governing of cultural frontier should be incorporated into the he country's governance systems and capabilities. On one hand, through perfecting the religious governance mechanism and resisting the religious infiltration, frontier ethical "cultural consciousness" will be enhanced and public cultural service system will be perfected. We will incorporate national dominant ideology into frontier ethnic culture and build an ideological place for the border areas; on the other hand, we will give full play to the functions of Civilorganizations and conduct civil exchange activities and promote the friendly exchanges between China and Myanmar; in the meanwhile, we will promote the development of ethnic culture industry and raise the ethnic cultural competence, through which the economic level of frontier ethnic minority areas will be enhances and it is of great benefit to the harmonious and stable development of the frontier ethnic minority areas. 


\section{REFERENCES}

[1] Eva Hung.2005.Translation \& Cultural Change: case studies in history, norms and image-projection, Amsterdam and Philadelphia:John Benjamins, p. 43.(In Chinese)

[2] Yang Cheng. Benefit Frontier: The Developmental Connotation of National Sovereignty. Modern International Relations, Issue 11, 2003, p. 19. (In Chinese)

[3] Xu Lili. The Extension of National Interests and The Development of Soft Frontier Concept. Journal of Yunnan Normal University (Philosophy and Social Sciences Edition), 2011, (5), p. 45. (In Chinese)
[4] Dong Jiangai. Border Culture Governance Research in China's National Cultural Security, Exploration, Issue 04, 2016, p. 65. (In Chinese)

[5] Su Cuiwei. Research on Christian Governance in Sino-Burmese Border Area [J]. World Religious Culture, 2016 (3), p. 90. (In Chinese)

[6] Wang Xia. Chinese Cultural Identity and Frontier Culture Security in Ethnic Areas, Heilongiiang National Series, Issue 05, 2012, p. 47. (In Chinese)

[7] Wu Lina. Cultural Security Strategy Thinking in Southwest Border Areas, The Guide of Science \& Education, Issue 03, 2016, p. 134. (In Chinese) 